\title{
The salutary effect of milk on amoebiasis and its reversal by iron
}

\author{
M J MURRAY, ANNE MURRAY, C J MURRAY
}

\section{Summary and conclusions}

Observations among milk-drinking African nomads showed an unusual freedom from infection with Entamoeba histolytica compared with similar nomads taking a mixed diet. A controlled study among Maasai pastoralists showed that the administration of iron to correct their dietary iron deficiency sharply increased their susceptibility to amoebiasis. Examination of the milk of their Zebu cattle showed that it not only had a concentration of iron below the minimum necessary for the growth of $E$ histolytica but also contained partly saturated lactoferrin and transferrin, which may actively compete with the parasite in the colon for ambient iron.

These observations suggest the possibility of a longstanding ecological compromise between nomads, their milk diet, and $\mathrm{E}$ histolytica.

\section{Introduction}

For some time we have suspected the possibility of an ecological interdependence of diet and infection in tribal societies favouring the harmonious coexistence of man and certain pathogenic organisms. ${ }^{1}$ We present observations to support such a relationship in milk-drinking nomadic tribes whose nearly all-milk diet appears to favour suppression of infection with Entamoeba histolytica.

The salutary effect of milk on infection in animals has already been reported. ${ }^{2}$ A diet of cows' milk, although an unnatural one for mice and monkeys, will suppress infection when mice are inoculated with Plasmodium berghei and monkeys with $P$ cynomolgi. ${ }^{3}$ This effect has been attributed to the near absence of paraminobenzoic acid (PABA) in the cows' milk. ${ }^{4}$ PABA is not essential for man, but it appears essential for certain plasmodia which cannot use preformed folate. ${ }^{5}$ Observations on milk-drinking Somali nomads, many of whom are iron-deficient, have shown an apparent suppression of malaria (as well as other micro-organisms favouring an intracellular location) which has been readily reversed by iron repletion. ${ }^{6}$ A study of the effect of diet on infections in milk-drinking Turkana nomads in northern Kenya unexpectedly showed serological evidence of an unusual freedom from infection with $E$ histolytica when compared with findings in Turkana living in the same area but consuming a mixed diet. ${ }^{7}$ We therefore undertook a controlled study of the relationship of a milk diet to infection with $E$ histolytica among Maasai in the Rift Valley of Kenya.

\section{Methods}

A random sample of 81 adult Maasai from three neighbouring villages centred on Seikeri and situated on an eastern tier of the Rift Valley was first studied for past and present evidence of amoebiasis. Their water was obtained from a muddy hole used by cattle, wild animals, and people alike for drinking and washing. There was no

University of Minnesota Medical School, Department of Medicine, Minneapolis, Minnesota 55455, USA

M J MURRAY, MD, FRCP, professor of medicine

ANNE MURRAY, BHSC, research assistant

C J MURRAY, student proper sewage disposal in the villages and flies were numerous on eating utensils (gourds) and body surfaces. Two Maasai had cysts of $E$ histolytica, none had active amoebae in their stools, but three had serological evidence of past infection by the latex agglutination test (Serameba, Ames, Elkhart, Indiana 46514). The Maasai have a reputation for drinking animal blood, but in our experience this practice is now limited to men on ceremonial occasions or to display for visitors. All Maasai in this study were observed to consume milk as the major item in their diet.

We then conducted a prospective study from August 1977 to August 1978 on the 76 Maasai free of intestinal or serological evidence of infection with $E$ histolytica. In August of 1977 we collected two samples of milk in an iron-free plastic container from Zebu cattle in each of the three villages for determining the milk's iron content. ${ }^{8}$ Blood was taken from the Maasai in disposable plastic syringes for determining haemoglobin concentration using an optical haemoglobinometer (Model 1010D, American Optical Company, Buffalo, New York 19215), serum iron concentrations, ${ }^{9}$ and transferrin saturation. ${ }^{10}$ Serum ferritin or stainable iron in bone-marrow would have been better measures of iron deficiency but neither could be measured in the field. The response to treatment with iron confirmed iron deficiency as the cause of low transferrin saturation in the Maasai in this study.

The 76 were then divided into two groups of 35 each (groups 1 and 2) matched for age and sex and one group of six (group 3). Table I records the findings in the Maasai and in milk samples. The Maasai

TABLE I-Iron content of Zebu milk and levels of haemoglobin, serum iron, and transferrin saturation of Maasai in August 1977. Values are means $\pm S E$

\begin{tabular}{|c|c|c|c|c|c|c|c|}
\hline & & & & No & $\underset{(\mu \mathrm{mol} / \mathrm{l})}{\text { Iron }}$ & $\underset{(\mathrm{g} / \mathrm{dl})}{\text { Haemoglobin }}$ & $\begin{array}{c}\text { Transferrin } \\
\text { saturation } \\
(\%)\end{array}$ \\
\hline $\begin{array}{l}\text { Milk } \\
\text { Maasai }\end{array}$ & .. & 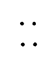 & $\because$. & $\begin{array}{r}6 \\
76\end{array}$ & $\begin{array}{l}5 \cdot 9 \pm 2 \cdot 8 \\
6 \cdot 8 \pm 0.7\end{array}$ & $11.9 \pm 0.8$ & $14 \cdot 7 \pm 2 \cdot 4$ \\
\hline
\end{tabular}

Conversion: SI to traditional units-Serum iron: $1 \mu \mathrm{mol} / 1 \approx 5.6 \mu \mathrm{g} / 100 \mathrm{ml}$.

were all mildly iron deficient, a finding already observed in milkdrinking nomads ${ }^{11}$ and largely attributed to the poor supply of iron in animal milk. ${ }^{6}$ Maasai in group 1 served as controls and were given no treatment. Those in group 2 were given one $300-\mathrm{mg}$ tablet of ferrous sulphate containing $60 \mathrm{mg}$ of iron twice weekly for one year to correct their dietary iron deficiency. The tablets were distributed by an elder in each village. The six Maasai in group 3 elected to receive iron by injection rather than by mouth and were given six once-weekly intramuscular injections of $100 \mathrm{mg}$ of iron as iron dextran after a preliminary test dose of $20 \mathrm{mg}$. This amount was calculated to restore haemoglobin levels to normal. All those receiving iron were told to stop treatment and report immediately if they developed fever, abdominal pain, severe or persistent diarrhoea, or rectal bleeding. Curiously, there were no complaints of abdominal pain or diarrhoea, but attacks of malaria occurred and were promptly treated in six of those receiving oral iron and one receiving iron dextran injections. None of the controls were affected. In August 1978 two further samples of milk from each village were examined for total iron. Stools from all groups were examined for cysts and amoebae of $E$ histolytica while blood was tested for serological evidence of amoebic infection, haemoglobin concentration, and transferrin saturation.

\section{Results}

Table II records the results. The iron content of the milk samples in 1978 was not significantly different from that in 1977 . The infection rate with $E$ histolytica in group 1 was low but rose sharply and 
significantly in group 2, regardless of the village of origin. Surprisingly, no infection with $E$ histolytica occurred among the six Maasai treated with parenteral iron despite the return of their iron state to normal. All those showing intestinal or serological evidence of infection with $E$ histolytica were treated with a single course of metronidazole. Stools became negative for cysts and amoebae in all those previously positive.

TABLE II-Iron content of Zebu milk and concentrations of haemoglobin and serum iron, transferrin saturation, and intestinal and serological evidence of infection with $E$ histolytica in Maasai with and without iron supplementation in August 1978. Values are means $\pm S E$

\begin{tabular}{|c|c|c|c|c|c|c|c|}
\hline & \multirow[b]{2}{*}{ No } & \multirow{2}{*}{$\underset{(\mu \mathrm{mol} / \mathrm{l})}{\text { Iron }}$} & \multirow{2}{*}{$\underset{(\mathrm{g} / \mathrm{dl})}{\text { Haemoglobin }}$} & \multirow{2}{*}{$\begin{array}{c}\text { Transferrin } \\
\text { saturation } \\
(\%)\end{array}$} & \multicolumn{3}{|c|}{$E$ histolytica infection } \\
\hline & & & & & $\begin{array}{l}\text { Cysts } \\
\text { only }\end{array}$ & $\begin{array}{c}\text { Amoebae } \\
\text { only }\end{array}$ & $\begin{array}{l}\text { Positive } \\
\text { sera }\end{array}$ \\
\hline $\begin{array}{l}\text { Milk (1978) } \\
\text { Group } 1 \\
\text { Group } 2 \\
\text { Group } 3\end{array}$ & $\begin{array}{r}6 \\
35 \\
35 \\
6\end{array}$ & $\begin{array}{c}6 \cdot 2 \pm 2 \cdot 7 \\
6 \cdot 7 \pm 0 \cdot 9 \\
10 \cdot 8 \pm 1 \cdot 3 * \\
11 \cdot 0 \pm 1 \cdot 2\end{array}$ & $\begin{array}{l}11 \cdot 7 \pm 0.8 \\
13 \cdot 1 \pm 1 \cdot 2 * \\
12 \cdot 9 \pm 0.7\end{array}$ & $\begin{array}{l}14 \pm 2 \cdot 6 \\
29 \pm 3 \cdot 1^{*} \\
31 \pm 2 \cdot 7\end{array}$ & $\begin{array}{c}1 \\
11^{*}\end{array}$ & $\begin{array}{l}0 \\
7^{*} \\
0\end{array}$ & $\begin{array}{c}3 \\
29+* \\
0\end{array}$ \\
\hline
\end{tabular}

*All significantly different $(\mathrm{p}<0.001)$ from group 1 by Student's $t$ test.

+ Includes those with cysts and amoebae.

Conversion: SI to traditional units-Serum iron: $1 \mu \mathrm{mol} / 1 \approx 5.6 \mu \mathrm{g} / 100 \mathrm{ml}$.

\section{Discussion}

The iron content of cows' milk is low. ${ }^{12}$ Most of it is either bound to the iron-binding proteins lactoferrin and transferrin, which are rarely saturated beyond $30 \%$ of their capacity, ${ }^{13}$ or contained in the enzymes xanthine oxidase, lactoperoxidase, and catalase ${ }^{14}$ Since the requirement of iron (as ferric chloride) for optimal growth and multiplication of $E$ histolytica is high, probably about $44 \mu \mathrm{mol} / 1(246 \mu \mathrm{g} / 100 \mathrm{ml})^{15}$ (compared with 0.3 to $1.8 \mu \mathrm{mol} / 1(1 \cdot 7-10 \mu \mathrm{g} / 100 \mathrm{ml})$ for many Gram-negative organisms ${ }^{16}$ ), we argued as follows. The poor supply of iron in milk, its biological unavailability, and the competition of partially saturated lactoferrin and transferrin with the amoebae for ambient iron might discourage growth or invasiveness of the parasite, or both.

The samples of Zebu milk contained an average of $6 \mu \mathrm{mol} / 1$ $(34 \mu \mathrm{g} / 100 \mathrm{ml})$ of iron. Allowing an average content of $4.5 \mu \mathrm{mol} / 1$ $(25 \mu \mathrm{g} / 100 \mathrm{ml})$ of iron in the enzymes, ${ }^{14}$ then only $1.5 \mu \mathrm{mol} / 1$ $(9 \mu \mathrm{g} / 100 \mathrm{ml})$ of iron would be available for binding to lactoferrin and transferrin; about $100 \mathrm{mg}$ of each would be present in a litre of milk with a binding capacity of $1.4 \mu \mathrm{g} / \mathrm{mg}$. Assuming similar avidities for iron (lactoferrin does have a higher association constant) then $45 \mu \mathrm{g}$ of iron would bind to each $100 \mathrm{mg}$ of protein for a saturation of $32 \%$. Since the minimum concentration of iron for growth of $E$ histolytica is $12 \mu \mathrm{mol} / 1$ $(67 \mu \mathrm{g} / 100 \mathrm{ml})^{15}$ conditions in the colon must be far from favourable for $E$ histolytica on the all-milk diet of the Maasai with its total iron concentration at $6 \mu \mathrm{mol} / 1(34 \mu \mathrm{g} / 100 \mathrm{ml})$, much of which may be unavailable. Amoebae probably cannot leach iron from transferrin or lactoferrin at a saturation of $32 \%$, and the transferrin and lactoferrin probably compete successfully with the amoebae for free iron. After absorption of iron in the upper gut and dilution of the remainder by secretions the concentration of iron in the colon must be low. Although lactoferrin and transferrin are susceptible to tryptic digestion, the effect is less pronounced with forms partly saturated than with the apoprotein while fragments resulting from digestion may still have significant capacity to bind iron in the gut. ${ }^{17} E$ histolytica can digest red cells, but this ability may depend on its invasive qualities, which may not develop in a medium of low iron. Furthermore, iron-deficient red cells may not themselves provide enough iron. It is not known whether amoebae can digest cells desquamating from colonic mucosa and extract their iron. Even if they could the iron content of those cells on an all-milk diet may be very low. The amoebae may digest and use the iron of colonic bacteria, but in Maasai on an all-milk diet lactobacilli are likely to be the predominant species in the colon. Lactobacilli contain very little iron and may require none for growth and replica- tion. ${ }^{18}$ The fact that no infection occurred in those receiving iron by injection suggests that it may be the intestinal content of iron rather than the iron state of the body which is important in controlling growth of $E$ histolytica.

Our observations suggest that cows' milk as a staple diet may protect tribal societies against infection with $E$ histolytica. This effect is more likely because of the low iron content of milk and the competition of its iron-binding proteins with the amoebae for iron rather than because of tissue iron deficiency of the host. We suspect these findings represent a longstanding ecological compromise between man, diet, and micropredators; the milk permits the nomad to live in a hostile environment infected with amoebae at the price of mild iron deficiency. The reverse phenomenon may be true in the Zulu, whose traditional diet and drink, high in iron, may foster frequent and severe amoebiasis. ${ }^{19}$

\section{References}

${ }^{1}$ Murray MJ, Murray AB, Murray NJ, Murray MB, Murray CJ. Malaria and ascariasis-reply to letter by Stephenson and Latham. Am $\mathcal{F}$ Nutr $1979 ; 32: 732-3$.

${ }^{2}$ Maegraith BJ, Deegan T, Hanes E. Suppression of malaria ( $P$ berghei) by milk. $B r$ Med $\mathcal{J} 1952 ;$ ii :1382-3.

${ }^{3}$ Bray RS, Garnham PCC. Effect of a milk diet on $P$ cynamolgi infections in monkeys. Br Med f 1953;ii:1200-1.

4 Hawking F. Milk diet, $p$-aminobenzoic acid and malaria ( $P$ berghei). Br Med f 1953;ii:1201-2.

${ }^{5}$ Anfinsen CB, Geiman O, McKee R, Ormsbee R, Ball EG. Studies on malarial parasites. viii. Factors affecting the growth of Plasmodium knowlesi in vitro. $\mathcal{F}$ Exp Med 1946;74:607-21.

${ }^{6}$ Murray MJ, Murray AB, Murray MB, Murray CJ. Adverse effects of iron repletion of the course of some infections. $\mathrm{Br}$ Med $\mathcal{f} 1978$;ii: 1113-5.

${ }^{7}$ Murray MJ, Murray AB, Murray CJ. An ecological interdependence of diet and disease? A study of infection in one tribe consuming two different diets. Am $\mathcal{F}$ Clin Nutr 1980;33:697-701.

${ }^{8}$ Murray MJ, Murray AB, Murray NJ, Murray MB. The effect of iron status of Nigerian mothers on that of their infants at birth and 6 months, and on the concentration of $\mathrm{Fe}$ in breast milk. Brit $\mathcal{F}$ Nutr 1976;39: 627-30.

${ }^{9}$ Nelson CV. Determination of serum iron using sulfonated diphenyl phenanthroline. Am 7 Med Technol 1964;30:71-80.

10 Herbert V, Gottlieb CW, Kam-Seng L, Fisher M, Gevitz NR, Wasserman LR. Charcoal coated assay of unsaturated iron-binding capacity. $\mathfrak{f}$ Lab Clin Med 1966;67:855-8.

11 Lappicerella V, Lappicerella R, Abboni F, Leotta S. Enquête clinique, biologique et cardiographique parmi les kribus nomades de la Somalie qui se nourissent seulement de lait. Bull Wld Hlth Org 1971 ;10:681-97.

12 Masson PL, Hereman JF. Lactoferrin in milk from different species. Comp Biocyem Physiol 1971;39B:119-29.

13 Masson PL, Hereman JF. Metal combining properties of human lactoferrin. Europ $\mathcal{F}$ of Biochem 1968;6:579-84.

14 Groves ML. In: McKenzie HA ed. Milk proteins-chemistry and molecular biology. Vol II. New York: Academic Press, 1971.

15 Latour NH, Reeves RE. An iron requirement for growth of Entamoeba histolytica in culture and the anti-amebae activity of 7-iodo-8-hydroxyquinolone-5-sulfonic acid. Exp Parasitol 1965;17:203-19.

16 Weinberg ED. Iron susceptibility to infectious disease. Science 1974; 184:952-6.

17 Brock JH, Azzabe F, Lawpreave F, Pineiro A. Effect of trypsin on bovine transferrin and lactoferrin. Biochim Biophys Acta 1976;446:214-25.

18 Neilands JB. Microbial iron metabolism. New York: Academic Press, 1974.

19 Diamond LS, Harlow DR, Phillips BR, Keister DB. Entamoeba histolytica -iron and nutritional immunity. Arch Invest Med (Mex) 1978;9, suppl $1: 329-38$.

(Accepted 6 March 1980)

ONE HUNDRED YEARS AGO An order has been issued from the Home Office, through the Chief Commissioner of Police, directing that when boys brought before the courts of summary jurisdiction are ordered by the magistrates to be whipped, in accordance with the provisions of the Act which came into operation at the beginning of the year, a medical man shall be present at the carrying out of the sentence. The order also fixes the scale of remuneration which the medical attendant shall receive-viz., for the first boy, $5 \mathrm{~s}$.; and for every succeeding one, 3s. 6d. (British Medical fournal, 1880.) 